Research Article

Eethar Thanon Dawood* and Mafaz Hani Abdullah

\title{
Behavior of green reactive powder mortar reinforced with steel fibers
}

https://doi.org/10.1515/jmbm-2021-0014

Received Apr 27, 2021; accepted Aug 15, 2021

\begin{abstract}
The use of supplementary cementitious materials like crushed glass, steel slag, and silica fume at an acceptable level has resulted in many advantages such as reduction of the waste solid materials and production of eco-friendly material. Moreover, the inclusion of fibers for reinforcing cementitious matrix can improve its properties overall. Therefore, this research has been divided into two phases. The first phase has included the production of green reactive powder mortar and the investigation of its properties. The second phase has involved the incorporation of the micro steel fibers to green reactive powder mortar with different amounts. The results have indicated that the use of the crushed glass, steel slag, and silica fume by 8,12 , and $10 \%$ as a partial replacement of cement with suitable chemical admixture gives a great reduction of cement by $30 \%$ from the total cementitious amount used in reactive powder mortar and greater values of strengths for reactive powder mortar. The addition of micro steel fibers by 1, 1.5, 2, and $2.5 \%$ improves the dry bulk density, ultrasonic pulse velocity, compressive strength, flexural strength, and tensile strength of green mortar. The best increase has been observed at green reactive powder mortar (GRPC) containing $2 \%$ of micro steel fibers.
\end{abstract}

Keywords: micro-steel fibers, reinforced mortar, green reactive powder mortar, mechanical properties

\section{Introduction}

Ultrahigh performance concrete or reactive powder concrete is one of the best cementitious composites which have

\footnotetext{
*Corresponding Author: Eethar Thanon Dawood: Building and Construction Eng. Technical College of Mosul, Northern Technical College of Mosul, Northern Technical University, Iraq, E-mail: eethar2005@yahoo.com

Mafaz Hani Abdullah: Building and Construction Eng. Technical College of Mosul, Northern Technical College of Mosul, Northern Technical University, Iraq
}

been used in many applications such as highways and for repairing damaged structures $[1,2]$ due to its good physical and mechanical properties. This type of building material has characterized by high compressive strength, tensile strength, flexural strength, flexural toughness, and high flowability which allow it to flow in congested reinforcement areas and fill complicated formwork segregating [3-6]. Several researchers tried to improve the mechanical properties of reactive powder concrete and used supplementary cementitious materials like crushed glass, fly ash, ceramic, slag, or silica fume as partial substituted of cement [7-11]. The utilization of crushed glass, steel slag, or/and silica fume has a positive impact on the environment on the one hand and the mechanical properties of mortar on the other hand [12-14]. Islam et al. [15] have noticed that the partial replacement of cement by glass powder affects the flowability and compressive strength of cement mortar and concrete. The influence of crushed glass is dependent on the fineness, the amount used and curing age of the cementitious matrix. Zhang et al. [16] have found that the inclusion of silica fume into cementitious composites leads to enhance the interface bond strength between hardened cement paste and aggregate. Consequently, silica fume contributes to improving the strength of cement paste, mortar, and concrete. Roslan et al. [17] have investigated the pozzolanic activity of steel slag in the cementitious matrix. They found that the inclusion of such material in concrete improves compressive strength, tensile strength, and flexural strength. The effect of silica fume, steel, and iron slag, or glass powder is associated with the amount used in the cementitious matrix [18]. The use of a high dosage of each one of such materials has a negative impact on the cement mortar or concrete properties. The presence of a high amount of silica fume in mortar or concrete contributes to increasing the heat of hydration and the agglomeration of silica fume particles which may reduce the strength of cement-based composites [16, 19]. Although the glass powder can be utilized as partial compensation for cement, the replacement of a high amount of cement by glass powder contributes to decreasing the strength [20]. The same thing can be observed at the early age of mortar or concrete which contained a high amount of slag as a partial replacement of cement [21]. The reduction of strength can be attributed to many reasons like the cal- 
cium silicate hydrate gel resulted from cement is stronger than that of glass powder or slag, the particle size of the material, and curing type and age [21-23]. Therefore, the present study has highlighted the use of a suitable mixture of silica fume, glass powder, and slag as a partial replacement of cement to produce green reactive powder mortar containing $30 \%$ replacement of cement with preserving the excellent properties.

Although the use of supplementary cementitious materials (like silica fume, glass powder, or slag) can improve the properties of mortar or concrete, it does not contribute to converting the brittle material to ductile material. The incorporation of fibers into cement mortar or/and concrete has been documented by many researchers [24-28]. The addition of steel fibers to the plain cementitious matrix can improve greatly the toughness and impact behavior [29]. Noori et al. [30] studied the behavior of non-reinforced and reinforced high-strength mortar under tri-axial compression conditions. They have concluded that the addition of brasscoated steel fibers with a length of $13 \mathrm{~mm}$ and diameter of $0.175 \mathrm{~mm}$. to the plain matrix helped to increase the energy absorption capacity of cement mortar and made it more ductile. Shelake et al. [31] conducted the compression test, flexural test, shear test, and tension test on the specimens of reactive powder concrete reinforced with fibers (fibers of corrugated carbon steel wire) at different curing conditions. They have observed that the compressive strength and tensile strength increase with increase curing temperature while the flexural strength and shear strength increase with increasing steel fibers volume fraction in the concrete. Hassani et al. [32] have investigated the mechanical properties of concrete that contained the silica fume as partial replacement of cement and included the hooked steel fibers with a length of $30 \mathrm{~mm}$., and diameter of $0.5 \mathrm{~mm}$. They have noticed that the increasing silica fume content in the concrete leads to an increase the compressive strength. Also, the reinforcing of concrete with hooked steel fibers leads to enhance the tensile strength, flexural strength, and loaddeflection behavior. Consequently, the steel fibers give the concrete high ductility and fracture toughness. Many researchers [33-35] conducted the ultrasonic pulse velocity test on the high-performance mortar or/and concrete. Hassan et al. [36] incorporated the steel fibers into the cementitious matrix and conducted non-destructive tests. They concluded that these fibers increase the ultrasonic pulse velocity and improve the density of the cementitious matrix. Moreover, the effect of fibers in cement-based composites is depended on the fiber's properties and the amount of fibers used.

The main objectives of this study are:
1) The utilization of a suitable mixture of silica fume, slag, and glass powder as a partial substitution of cement to produce green reactive powder mortar;

2) Reinforcing the green mortar produced by using the optimal amount of micro- steel fibers to give it superior properties.

\section{Experimental study}

\subsection{Materials}

Ordinary Portland Cement (OPC) was utilized in this study. It was (CEM I) of strength class $42.5 \mathrm{~N}$. This cement was conforming to Iraqi Specifications IQS and the commercial name is Delta. Densified Micro-silica (SF) was bought from MSASA-Construction Solutions for Africa, Pomona AH, South Africa. Slag (SG) was brought from the factory of iron production, Mosul, Iraq. Crushed glass (CG) was supplied by a glass recycling plant, Mosul, Iraq. The physical properties and chemical composition of OPC, SF, SG, and CG are listed in Table 1. The pozzolanic activity index of materials (silica fume, crushed glass, and slag) was measured at age of 7 and 28 days in previous work [18] .

Local river sand was utilized in this study. It was used as a fine aggregate in all mixes after preparing it according to ASTM C778 [37]. The bulk dry density and absorption of this sand were 2.510 , and $2.66 \%$ respectively. The chemical composition of this sand was given in Table 2. An innovative polycarboxylic ether superplasticizer (SP) was utilized to improve the workability of all mixes. It was procured from Marla-Chemicals company, Istanbul, Turkey. Its commercial name is RB-1070. Defoamer (De.) was used in all mixes for removing trapped air in the produced mortar and to increase the density and strength of produced mortar. It was bought from Marla-Chemicals company, Istanbul, Turkey. Workability retaining plasticizer (Re) was used to retain the workability without retardation. It was procured from Marla-Chemicals company, Istanbul, Turkey. Its commercial name is KUR 60. The typical characteristics of superplasticizer, Defoamer, and workability retaining plasticizer are given in Table 3-5. Tap water was used in all mixes. Micro steel fibers (MSF) were procured from Jiangsu Bositai Steel Fiber Co., Ltd., Maqiao, China. This type of fiber has a low quantity of carbon and they are coated by copper. The fibers were used by $1 \%, 1.5 \%, 2 \%$, and $2.5 \%$ of the total volume of mortar to improve the properties of green reactive powder mortar. The properties of these fibers are listed in Table 6. 
Table 1: Physical properties and chemical composition of the OPC, CG, SG and SF.

\begin{tabular}{lllll}
\hline Physical properties & OPC & CG & SG & SF \\
\hline Specific gravity, gm $/ \mathrm{cm}^{3}$ & 3.15 & 2.315 & 4.994 & 1.98 \\
Blaine's fineness, $\mathrm{cm}^{2} / \mathrm{gm}$ & 3560 & 4094 & 8028 & - \\
\hline Chemical composition (\% wt.) & & & & \\
\hline Ferric oxide, $\mathrm{Fe}_{2} \mathrm{O}_{3} \%$ & 3.44 & 1.168 & 95.430 & 0.795 \\
Calcium oxide, $\mathrm{CaO} \%$ & 61.46 & 11.940 & 0.646 & 1.436 \\
Silicon dioxide, $\mathrm{SiO}_{2} \%$ & 19.53 & 72.71 & 4.027 & 93.29 \\
Potassium oxide, $\mathrm{SO}_{3} \%$ & 2.25 & 0.323 & 0.837 & 0.851 \\
Alkalies $\left(\mathrm{K}_{2} \mathrm{O}+\mathrm{Na}_{2} \mathrm{O}\right) \%$ & 0.58 & 8.906 & 1.078 & 0.875 \\
Manganese oxide, $\mathrm{MnO} \%$ & - & 0.014 & 0.496 & 0.043 \\
Magnesium oxide, $\mathrm{MgO} \%$ & 3.82 & 1.480 & 0.141 & 0.137 \\
Aluminum oxide, $\mathrm{Al}_{2} \mathrm{O}_{3} \%$ & 4.92 & 1.487 & 0.523 & 0.264 \\
Loss of ignition, $\%$ & 3.11 & - & - & - \\
$\mathrm{C}_{3} \mathrm{~S} \%$ & 57.39 & - & - & - \\
$\mathrm{C}_{2} \mathrm{~S} \%$ & 13.53 & - & - & - \\
$\mathrm{C}_{3} \mathrm{~A} \%$ & 7.20 & - & - & - \\
$\mathrm{C}_{4} \mathrm{AF} \%$ & 10.46 & - & - & - \\
\hline
\end{tabular}

Table 2: Chemical composition of local river sand.

\begin{tabular}{llllllll}
\hline \multicolumn{7}{c}{ Chemical composition (\%wt.) } \\
\hline $\mathrm{CaO} \%$ & $\mathrm{SiO}_{2} \%$ & $\mathrm{Al}_{2} \mathrm{O}_{3} \%$ & $\mathrm{Fe}_{2} \mathrm{O}_{3} \%$ & $\mathrm{MnO} \%$ & $\mathrm{MgO} \%$ & $\mathrm{~K} 20 \%$ & $\mathrm{Na}_{2} \mathrm{O} \%$ \\
\hline 9.029 & 75.49 & 2.965 & 2.716 & 0.042 & 1.019 & 3.142 & 1.673 \\
\hline
\end{tabular}

\subsection{Mix proportions}

In this research, seven mixes of ultra-high performance mortar were prepared, three (3) of them were non-reinforced with Micro steel fibers and another four mixes were reinforced with Micro steel fibers. All these mixes were prepared by using a binder $(\mathrm{OPC}+\mathrm{SF}+\mathrm{SG}+\mathrm{CG}) /$ sand ratio of 1:1 by mass. Water $(\mathrm{W})+$ Chemical admixtures/binder ratio was 0.3. Superplasticizer (SP) was used in a maximum dosage of $1 \%$ by weight of binder (OPC+SF+SG+CG). Defoamer (De) was used in a maximum dosage of $0.3 \%$ by weight of superplasticizer. Workability retaining plasticizer (Re) was used in a minimum dosage of $0.3 \%$ by weight of binder $(\mathrm{OPC}+\mathrm{SF}+\mathrm{SG}+\mathrm{CG})$. The details of non-reinforced and reinforced mixes are shown in Tables 7-8.

\subsection{Mixing procedure and flow-test}

All the mixes of ultra-high performance mortar (UHPM) were prepared according to the following steps sequentially: (a) Dry mixing of the binders OPC, SF, SG, and CG for 2 minutes.

(b) Addition of sand to the binders (OPC, SF, SG, and CG) and dry mixing for 2 minutes.

(c) Addition of $75 \%$ of the volume of water to the dry ingredients (binders with sand) and mixing it for 3 minutes.

(d) Addition of another $25 \%$ of the volume of water containing chemical admixtures which are superplasticizer, defoamer, or/and workability retaining plasticizer to the mixture and mixing it for 5 minutes.

(e) Addition of the micro steel fibers to the mixture and mix it for 7 minutes to obtain a homogeneous distribution of fibers in the mix for preparing reinforced green mortar.

As soon as the mixes of ultra-high performance mortar were prepared, the flow test was carried out. The standard test method for measuring the flow of hydraulic cement mortar according to ASTM C1437 [38] was followed to measure the flowability of non-reinforced and reinforced ultra-high performance mixes. In the flow- test, a mini-slump cone (the dimension of the inner base diameter is $100 \mathrm{~mm}$, the inner top diameter is $75 \mathrm{~mm}$. and the height of the cone is $55 \mathrm{~mm}$.) was filled with reactive powder mixture by two lay- 
Table 3: Typical characteristics of superplasticizer.

\begin{tabular}{llllll}
\hline \multicolumn{5}{c}{ Typical characteristics } \\
\hline Appearance & $\begin{array}{l}\text { Density }\left(\mathrm{gm} / \mathrm{cm}^{3}\right) \\
\end{array}$ & Chemical nature $25^{\circ} \mathrm{C}$ & $\mathrm{PH}$ & $\begin{array}{l}\text { Solid con- } \\
\text { tent }(\%)\end{array}$ & $\begin{array}{l}\text { Chloride } \\
\text { content(\%) }\end{array}$ \\
\hline Yellowish liquid & $1.110 \pm 0.02$ & New generation of syner- & $6.0 \pm 1$ & $50 \pm 2$ & $\begin{array}{l}\text { Less than } \\
\text { gistic special polymer }\end{array}$ \\
& & & & 0.10 \\
\hline
\end{tabular}

Table 4: Typical characteristics of De-foamer.

\begin{tabular}{lll}
\hline \multicolumn{3}{c}{ Typical characteristics } \\
\hline Appearance & Chemical nature & $\begin{array}{l}\text { Ionic } \\
\text { character }\end{array}$ \\
\hline Yellow, slight & Mixture with glycols & Nonionic \\
viscous & and emulsifiers & \\
\hline
\end{tabular}

ers, the thickness of each layer was about $27.5 \mathrm{~mm}$. and a mini tamping rode was used to compact the two layers by 20 blows for each one. Then the cone was removed slowly to allow the green reactive powder mortar (GRPM) mixture to flow evenly on the table. After that, the flow table was dropped 25 times and the average diameter of the flowing mixture was recorded. The average flow diameter of the non-reinforced ultra-high performance mixture was ranged from 128 to $138 \mathrm{~mm}$ as listed in Table 7 and for reinforced ultra-high performance mortar (UHPM) mixture was ranged from 123 to $130 \mathrm{~mm}$. as shown in Table 8 .

\subsection{Preparation and curing of samples}

After finishing the preparation of green mixtures and the flowability test, the samples were prepared (Figure 1(a)). All the mixes were poured into cast-iron molds. A total of 42 iron cubes of size $70.7 \times 70.7 \times 70.7 \mathrm{~mm}$ were cast for dry bulk density test and ultrasonic pulse velocity test ( 7 mixtures $\times 2$ ages $\times 3$ samples ) and the same number of specimens were prepared for measuring tensile strength. A total of 63 cubic specimens of size $50 \times 50 \times 50 \mathrm{~mm}$. and prismatic specimens of size $40 \times 40 \times 160 \mathrm{~mm}$. were poured for compression test and flexural test respectively ( 7 mixtures $\times 3$ ages $\times 3$ samples ). All specimens were prepared at room temperature $25 \pm 2^{\circ} \mathrm{C}$ and after $24 \mathrm{~h}$. of molding, the specimens were removed from the molds and cured by tap water at $55 \pm 5^{\circ} \mathrm{C}$ and tested at 7,28 , and 90 days.

\subsection{Testing of samples}

\subsubsection{Ultrasonic pulse velocity (UPV)}

After 30 minutes of putting out the specimens of size $70.7 \times 70.7 \times 70.7 \mathrm{~mm}$ from curing water, the specimens were subjected to the UPV test. These specimens were tested according to ASTM C597 [39] at age 28 and 90 days using an ultrasonic tester with a precision of $0.1 \mu \mathrm{s}$ (Figure 1(c)). The propagation time of ultrasound pulses through each sample was reported and the UPV value was estimated using Eq. (1):

$$
\mathrm{UPV}=\left[\frac{L}{T}\right] \times 1000
$$

Where UPV is the ultrasonic pulse velocity value $(\mathrm{m} / \mathrm{sec}), L$ is the distance between the transmitter and receiver $(70.7 \mathrm{~mm})$ and $T$ is the travel time $(\mu \mathrm{s})$.

\subsubsection{Dry bulk density (DBD)}

The dry bulk density test for the non-reinforced and reinforced GRPM was determined as per ASTM C642 (Standard Test Method for Density, Absorption, and Voids in Hardened Concrete) [40]. Three specimens of size $70.7 \times 70.7 \times 70.7$ $\mathrm{mm}$., for each mortar prepared in this study, were used to examine this test at 28 days and 90 days. The dry bulk density value for each specimen was evaluated using Eq. (2):

$$
\mathrm{DBD}=\left[\frac{A}{C-D}\right] \times \rho
$$

where $\mathrm{DBD}$ is the dry bulk density value, $A$ is the mass of oven-dried-specimen in air, $\mathrm{C}$ is the surface dry mass in the air after immersion till saturation completely and boiling for 5 hours, D is the apparent mass after drying completely, immersion until saturation and boiling for 5 hours, and $\rho$ is the density of water $\left(1 \mathrm{gm} / \mathrm{cm}^{3}\right)$. 
Table 5: Typical characteristics of workability retaining plasticizer.

\begin{tabular}{llllll}
\hline \multicolumn{5}{c}{ Typical characteristics } \\
\hline Appearance & $\begin{array}{l}\text { Density }(\mathrm{gm} / \mathrm{cm} 3) @ \\
25^{\circ} \mathrm{C}\end{array}$ & Chemical nature & PH & $\begin{array}{l}\text { Solid con- } \\
\text { tent }(\%)\end{array}$ & $\begin{array}{l}\text { Chloride } \\
\text { content(\%) }\end{array}$ \\
\hline Yellowish liquid & $1.107 \pm 0.02$ & $\begin{array}{l}\text { New generation of syner- } \\
\text { gistic polymer }\end{array}$ & $4.0 \pm 1$ & $60 \pm 2$ & $\begin{array}{l}\text { Less than } \\
\end{array}$ \\
& & & & 0.10 \\
\hline
\end{tabular}

Table 6: Properties of micro steel fiber.

\begin{tabular}{llllll}
\hline \multicolumn{6}{c}{ Properties } \\
\hline Type & $\begin{array}{l}\text { Average fiber } \\
\text { diameter }(\mathrm{mm})\end{array}$ & $\begin{array}{l}\text { Average fiber } \\
\text { length }(\mathrm{mm})\end{array}$ & $\begin{array}{l}\text { Aspect ratio } \\
(\mathrm{l} / \mathrm{d})\end{array}$ & $\begin{array}{l}\text { Tensile } \\
\text { strength }(\mathrm{MPa})\end{array}$ & $\begin{array}{l}\text { Specific gravity } \\
\left(\mathrm{gm} / \mathrm{cm}^{3}\right)\end{array}$ \\
\hline Straight & 0.225 & 13 & 58 & $>2850$ & 3.055 \\
\hline
\end{tabular}

\subsubsection{Compressive strength}

The compression test was conducted on $50 \mathrm{~mm}$ cube samples according to ASTM C109 [41]. The samples were tested using a digital compression-testing machine $(2000 \mathrm{kN}$. capacity) as shown in Figure 1(d) after 7, 28, and 90 days of water curing. Three samples were tested at each age and the average values were reported.

\subsubsection{Flexural strength}

The standard three-point flexural test which is conforming to ASTM C348 [42] was used for measuring flexural strength. This test involved the three-point flexural loading of small-scale prism specimens measuring $40 \times 40 \times 160 \mathrm{~mm}$. The flexural strength of specimens was determined at three different ages 7,28 , and 90 days using a digital compressiontesting machine $(2000 \mathrm{kN}$. capacity), as shown in Figure $1(\mathrm{e})$, and the average of three values of flexural strength measured was reported.

\subsubsection{Tensile strength}

The tension test was examined for the non-reinforced and reinforced green specimens, the dimensions of these specimens were shown in Figure 2. A tensile testing machine (9 KN. capacity) was used to measure the tensile strength of the specimens at age 28 and 90 days as shown in Figure 1(f). During this test, the maximum pullout load was reported and divided on the cross-section area at which the model failed according to Eq. (3):

$$
\mathrm{TS}=\left[\frac{\mathrm{L}}{A}\right] \times 1000
$$

Where TS is the tensile strength of hardened green sample (MPa), $\mathrm{L}$ is the maximum pullout load which bear by the sample before failure (KN.) and A is the cross-section area at which the model failed $\left(\mathrm{mm}^{2}\right)$.

\section{Results and discussions}

\subsection{Ultrasonic pulse velocity (UPV)}

Ultrasonic pulse velocity test was conducted through $70.7 \times 70.7 \times 70.7 \mathrm{~mm}$ specimens of reactive powder mortar without fibers and with fibers at age 28 and 90 days as demonstrated in Tables $9 \& 10$. The results in Table 9 show that the UPV of MC1 was higher than MC0 and MC2. The increase was by 1.3 and $1.9 \%$ at age 28 days and by 2 and $2.6 \%$ at age 90 days. The increase of UPV can be attributed to the use of supplementary cementitious materials (SCMs) in addition to the appropriate dosage of the chemical admixtures which led to densify mortar and decrease the cracks and the porosity of prepared mortar. Moreover, the addition of micro-steel fibers into the mix with different percentages contributed to increasing the UPV as shown in Table 10. This table listed the results of the UPV of reinforced green reactive powder concrete (RGRPM). The increase of UPV of RGRPM containing micro-steel fibers by $1,1.5,2$, and $2.5 \%$ was $1.3,1.9,3.3$, and $2 \%$ at age 28 day and by $0.01,1.3,2.7$, and $1.4 \%$ at age 90 days in comparison with reference mortar (MC1). This is due to good bond strength between steel fibers surface and produced mortar. So, it can be concluded that 
Table 7: Mix proportions of GRPM.

\begin{tabular}{lllllllllll}
\hline Index & $\begin{array}{l}\text { OPC } \\
\mathrm{Kg} \cdot \mathrm{m}^{-1}\end{array}$ & $\begin{array}{l}\mathrm{WGP} \\
\mathrm{Kg} \cdot \mathrm{m}^{-1}\end{array}$ & $\begin{array}{l}\mathrm{SG} \\
\mathrm{Kg} \cdot \mathrm{m}^{-1}\end{array}$ & $\begin{array}{l}\mathrm{SF} \\
\mathrm{Kg} \cdot \mathrm{m}^{-1}\end{array}$ & $\begin{array}{l}\text { Sand } \\
\mathrm{Kg} \cdot \mathrm{m}^{-1}\end{array}$ & $\mathrm{SP} \%$ & De $\%$ & Re \% & $\left(\mathrm{W}+\mathrm{CA}^{1}\right) / \mathrm{B}$ & Flow \% \\
\hline MC0 & 984 & 0 & 0 & 0 & 984 & 1 & 0.3 & 0 & 0.3 & 138 \\
MC1 & 680 & 78 & 117 & 97 & 972 & 1 & 0.3 & 0 & 0.3 & 130 \\
MC2 & 680 & 78 & 117 & 97 & 972 & 1 & 0.3 & 0.3 & 0.3 & 128 \\
\hline
\end{tabular}

${ }^{1} \mathrm{CA}=\mathrm{SP}+\mathrm{De}+\mathrm{Re}$

Table 8: Mix proportions of RGRPM.

\begin{tabular}{lllllllllll}
\hline Index & $\begin{array}{l}\text { OPC } \\
\mathrm{Kg} \cdot \mathrm{m}^{-1}\end{array}$ & $\begin{array}{l}\mathrm{CG} \\
\mathrm{Kg} \cdot \mathrm{m}^{-1}\end{array}$ & $\begin{array}{l}\mathrm{SG} \\
\mathrm{Kg} \cdot \mathrm{m}^{-1}\end{array}$ & $\begin{array}{l}\mathrm{SF} \\
\mathrm{Kg} \cdot \mathrm{m}^{-1}\end{array}$ & $\begin{array}{l}\text { Sand } \\
\mathrm{Kg} \cdot \mathrm{m}^{-1}\end{array}$ & $\begin{array}{l}\text { Steel } \\
\text { fibers } \%\end{array}$ & $\mathrm{SP} \%$ & De \% & $(\mathrm{W}+\mathrm{SP}+\mathrm{De}) / \mathrm{B}$ & Flow \% \\
\hline MC1 & 680 & 78 & 117 & 97 & 972 & 0 & 1 & 0.3 & 0.3 & 130 \\
MS1 & 680 & 78 & 117 & 97 & 972 & 1 & 1 & 0.3 & 0.3 & 128 \\
MS2 & 680 & 78 & 117 & 97 & 972 & 1.5 & 1 & 0.3 & 0.3 & 126 \\
MS3 & 680 & 78 & 117 & 97 & 972 & 2 & 1 & 0.3 & 0.3 & 123 \\
MS4 & 680 & 78 & 117 & 97 & 972 & 2.5 & 1 & 0.3 & 0.3 & 123 \\
\hline
\end{tabular}

the inclusion of steel fibers into the cementitious matrix led to an increase in the UPV and enhance the microstructure of high-strength mortar. This result agrees with previous studies conducted by Hassan et al. [36] and Nematzadeh et al. [43]. The ultrasonic pulse velocity of RGRPM was predicted using the results of compressive strength measured from experimental work, the content of micro-steel fibers used in the mixtures, and the ages of specimens tested. After applying multiple linear regression analysis, two models were proposed to predict UPV at age 28 and 90 days as shown below:

$U P V=4583.350+29.838 M S F+2.274$ Age $\ldots . . . M o d e l-1 a$ $U P V=2792.039+8.259 M S F+1.072$ Age + 20.764 CS........Model-1b

Where UPV is ultrasonic pulse velocity through specimens of reinforced green reactive powder concrete $\left(\mathrm{m} \cdot \mathrm{sec}^{-1}\right)$, MSF is the content of micro- steel fibers (\%) and age is the number of day (28 or 90$)$.

Table 9: The dry bulk density and UPV measured of reactive powder mortar (GRPM).

\begin{tabular}{lllll}
\hline Index & \multicolumn{2}{l}{ Dry bulk density $\left(\mathrm{Kg} \cdot \mathrm{m}^{-3}\right)$} & \multicolumn{2}{l}{ UPV. $\left(\mathrm{m} \cdot \mathrm{sec}^{-1}\right)$} \\
\cline { 2 - 5 } & 28days & 90days & 28days & 90days \\
\hline MC0 & 2510 & 2525 & 4.561 & 4.682 \\
MC1 & 2525 & 2538 & 4.621 & 4.777 \\
MC2 & 2503 & 2520 & 4.532 & 4.651 \\
\hline
\end{tabular}

The results of the UPV value predicted from the two models mentioned above and the prediction error (\%) were listed in Table 10. The results indicated that Model-1b is more reliable than Model-1a due to the prediction error (\%) was not excess -1.166 for negative values and 0.434 for positive values.

\subsection{Dry bulk density (DBD)}

The results in Table 9 indicated that the dry density of MC1 was higher than that of MCO and MC2. The increase was by 0.6 and $0.9 \%$ respectively at age 28 days and by 0.5 and $0.7 \%$ at age 90 days. The improvement in the density of MC1 compared to MCO can be attributed to the use of SCMs as a partial replacement of cement. The uses of crushed glass, steel slag, and silica fume have significant roles in enhancing the density. These materials can react with calcium oxide produced from cement hydration and form additional binder material, which is calcium silicate hydrate gel (C-S-H). Thus, it fills the gap between the cement paste and fine aggregate leading to an increase in the density of the mortar and decreases the porosity $[44,45]$. Besides, it can be noted that the specific gravity of steel slag (4.994 $\mathrm{gm} / \mathrm{cm}^{3}$ ) was higher than cement. So, the particles, which did not contribute to react and form new binder material, can contribute to increasing the density of mortar. Also, it was observed that the use of micro steel fibers by $1,1.5$, 2 , and $2.5 \%$ for reinforcing the best green reactive powder mortar (MC1) led to improve the density as shown in Table 11. The increase was by $1.0,1.4,1.8$, and $2.2 \%$ respectively 


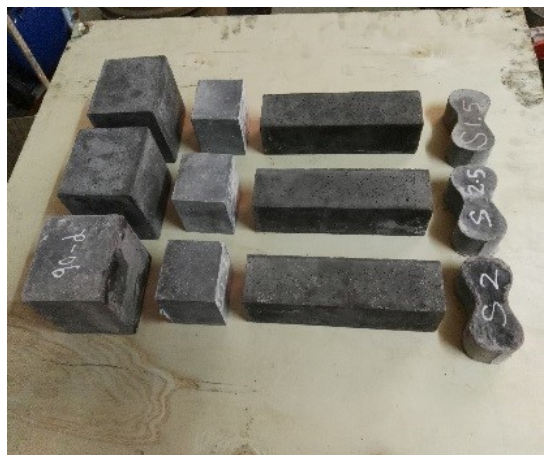

(a) Samples

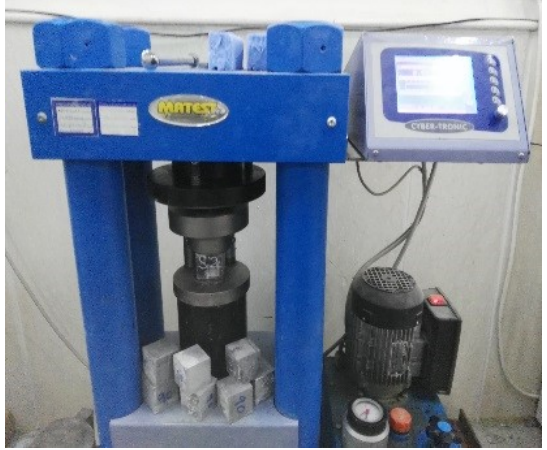

(d) Compression-test

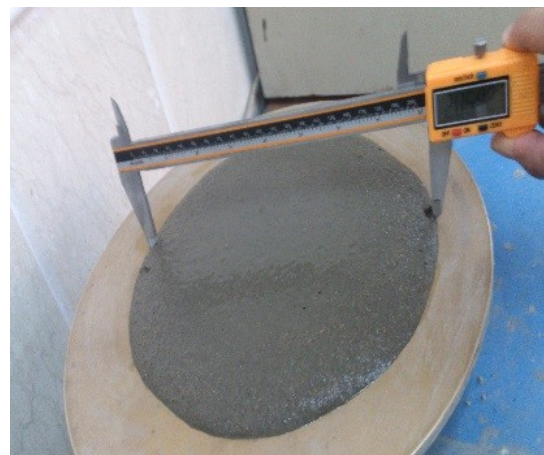

(b) Flow-test

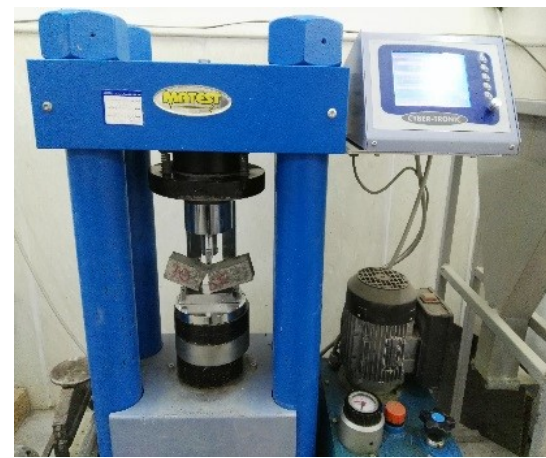

(e) Flexural-test

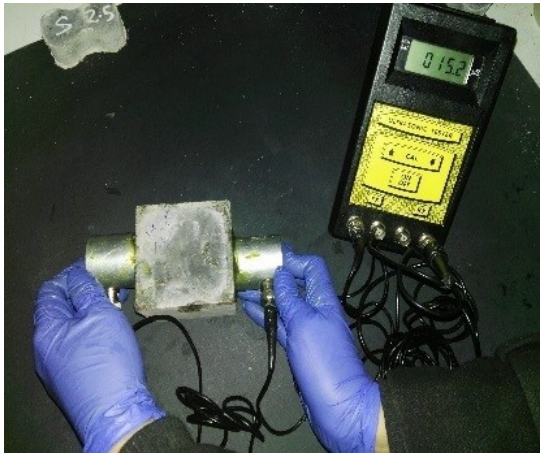

(c) UPV-test

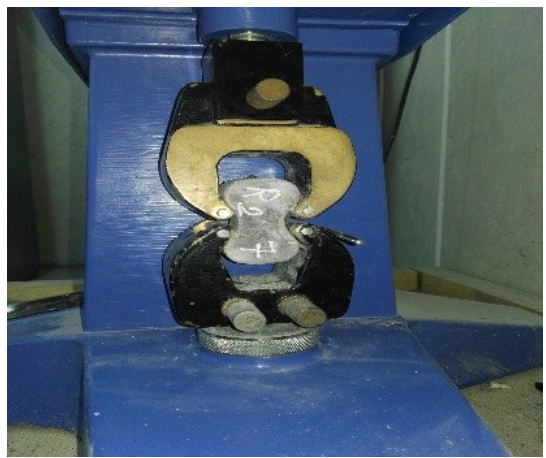

(f) Tension-test

Figure 1: Samples and machines used for testing.

at age 28 days and by $0.9,1.4,1.8$, and $2.1 \%$ at age 90 days. This is due to the specific gravity of micro-steel fibers which is higher than that of the mortar matrix [46]. Thus, it led to an increase in the density of GRPM generally. The dry bulk density (DBD) of specimens was related to the content of micro steel fibers and the duration of the treatment. Therefore, the content of micro-steel fibers and the age of sample mortar was used to predict the dry bulk density of GRPM. After applying multiple linear regression analysis, Model-2 was predicted as given below:

$D B D=2520.685+22.46 M S F+0.203$ Age $\ldots . .$. Model- 2

Where DBD is the dry bulk density predicted for reinforced green reactive powder mortar $\left(\mathrm{Kg}_{\mathrm{m}} \mathrm{m}^{-3}\right)$, MSF is the content of micro steel fibers (\%) and age is the number of days (28 or 90 ).

The results of DBD value predicted from Model-2 and the prediction error (\%) were shown in Table 11. The results indicated that Model-2 is reliable due to the prediction error (\%) was not excess -0.078 for negative values and 0.116 for positive values.

\subsection{Compressive strength}

Table 12 lists the obtained results from the compression test for ultra-high performance mortar at ages 7, 28, and 90 days. The results show that the MC1 had compressive strength higher than MCO and MC2. The increase was by 2.7 and $8.1 \%$ respectively at age 7 days and by 6.9 and $8.0 \%$ at age 28 and by 4.5 and $5.3 \%$ at age 90 days. The development of compressive strength of $\mathrm{MC} 1$ compared to $\mathrm{MCO}$ can be attributed to the partial replacement of cement by the crushed glass, steel slag, and silica fume at an acceptable level. The high content of amorphous silicon dioxide $\left(\mathrm{SiO}_{2}\right)$ with $72.71 \%$ and the small particle size of the crushed glass contributes to give the high pozzolanic activity [47, 48]. Moreover, the use of steel slag with a suitable amount can enhance the strength of mortar especially at late ages $[49,50]$. The high fineness of this material can fill the porosity of mortar and lead to an increase in the strength of mortar. Also, the use of silica fume as a partial substitute of cement has a significant role in the compressive strength of high strength mortar due to the high amount of amorphous silicon dioxide which react with calcium oxide resulted from cement hydration and lead to form additional calcium silicate hydrate (C-S-H) gel $[51,52]$. Also, the high fineness of silica fume makes it 
Table 10: UPV measured and predicted of reinforced green reactive powder concrete.

\begin{tabular}{|c|c|c|c|c|c|c|c|c|c|c|}
\hline \multirow[t]{2}{*}{ Index } & \multicolumn{2}{|c|}{$\begin{array}{l}\mathrm{UPV}\left(\mathrm{m} \cdot \mathrm{sec}^{-1}\right) \\
\text { measured }\end{array}$} & \multicolumn{2}{|c|}{$\begin{array}{l}U P V\left(m \cdot \sec ^{-1}\right) \\
\text { predicted from } \\
\text { Model-1a }\end{array}$} & \multicolumn{2}{|c|}{ Prediction error $2(\%)$} & \multicolumn{2}{|c|}{$\begin{array}{l}\text { UPV }\left(\mathrm{m} \cdot \mathrm{sec}^{-1}\right) \\
\text { predicted from } \\
\text { Model-1b }\end{array}$} & \multicolumn{2}{|c|}{$\begin{array}{l}\text { Prediction error }{ }^{2} \\
\text { (\%) }\end{array}$} \\
\hline & 28days & 90days & 28days & 90days & 28days & 90days & 28days & 90days & 28days & 90days \\
\hline MC1 & 4621 & 4777 & 4647 & 4788 & 0.563 & 0.23 & 4633 & 4764 & 0.26 & -0.272 \\
\hline MS1 & 4682 & 4810 & 4677 & 4818 & -0.107 & 0.166 & 4674 & 4813 & -0.171 & 0.062 \\
\hline MS2 & 4713 & 4842 & 4692 & 4833 & -0.446 & -0.186 & 4708 & 4863 & -0.106 & 0.434 \\
\hline MS3 & 4767 & 4910 & 4707 & 4848 & -1.259 & -1.263 & 4770 & 4907 & 0.063 & -0.061 \\
\hline MS4 & 4715 & 4845 & 4722 & 4863 & 0.148 & 0.372 & 4660 & 4802 & -1.166 & -0.888 \\
\hline
\end{tabular}

${ }^{2}$ Prediciton error $(\%)=($ Predicted value - measured value $) /($ measured value $) \times 100$

Table 11: The dry bulk density measured and predicted of RGRPM.

\begin{tabular}{lllllll}
\hline Index & \multicolumn{2}{c}{$\mathrm{DBD}\left(\mathrm{Kg} \cdot \mathrm{m}^{-3}\right)$ measured } & \multicolumn{2}{l}{$\mathrm{DBD}\left(\mathrm{Kg} \cdot \mathrm{m}^{-3}\right)$} & predicted & Prediction error \\
& & & from Model-2 & \\
& 28days & 90days & 28days & 90days & 28days & 90days \\
\hline MC1 & 2525 & 2538 & 2526 & 2539 & 0.04 & 0.039 \\
MS1 & 2550 & 2562 & 2549 & 2561 & -0.039 & -0.039 \\
MS2 & 2560 & 2575 & 2560 & 2573 & 0 & -0.078 \\
MS3 & 2572 & 2585 & 2571 & 2584 & -0.039 & -0.039 \\
MS4 & 2582 & 2592 & 2583 & 2595 & 0.039 & 0.116 \\
\hline
\end{tabular}

2 Prediciton error $(\%)=($ Predicted value - measured value $) /($ measured value $) \times 100$

work as filler materials in the cementitious matrix and gain the strength of mortar at an early and late age. Moreover, the decreasing strength of MC2 can be ascribed to the use of workability retaining plasticizer (Re). It was observed that the mortar contained admixture (MC2) has a delay in the initial and final setting time in comparison with MCO and MC1. On the other hand, the inclusion of micro steel fibers into the high-strength mortar can contributes to enhancing the compressive strength as shown in Table13. This table illustrated the results of compressive strength of green reactive mortar containing micro steel fibers. The results indicated that the use of $1,1.5,2$, and $2.5 \%$ of micro-steel fiber volume fractions improved the compressive strength compared to the control mix at different ages. The increase was $0.8,1.7,4.4$, and $0.3 \%$ at 7 days and $1.8,3.3,6.2$, and $0.3 \%$ at age 28 days and 2.1, 4.4, 6.3, and 0.9 at age 90 days. The development of the strength can be ascribed to the good bond strength between cementitious matrix and steel fibers. Besides, the reinforcement of mortar with steel fibers can delay the formation of micro-cracks and arrest their propagation afterward up to a certain extent of the fibers' volume fraction [46]. The compressive strength can be predicted using the obtained results of UPV from experimental work, the age of specimens, and the percentages of MSF used for preparing mixtures. After considering the UPV results, the percentages of MSF and age as independent variables, and compressive strength as a dependent variable, A multiple linear regression analysis was conducted. The result of regression analysis was given Model-3a and Model-3b as listed below:

$$
\begin{aligned}
& C S=82.749+0.911 M S F+0.106 \text { Age........Model-3a } \\
& C S=-121.906-0.316 M S F-0.045 \text { Age }+ \\
& 0.045 U P V . . . . . . . \text { Model-3b }
\end{aligned}
$$

Where CS is the compressive strength predicted (MPa), UPV is the ultrasonic pulse velocity measured $\left(\mathrm{m} . \mathrm{sec}^{-1}\right), \mathrm{MSF}$ is the content of micro steel fibers (\%) and age is the number of days $(7,28$, or 90$)$.

The compressive strength values predicted from Model3a and Model-3b and the prediction error (\%) were listed in Table 13a and 13b. The results indicated that Model-3b is more reliable than Model-3a due to the prediction error (\%) was not excess -3.19 for negative values and 0.82 for positive values. 
Table 12: The mechanical strength measured of GRPM.

\begin{tabular}{lllllllll}
\hline Index & \multicolumn{2}{c}{ Compressive strength (MPa) } & \multicolumn{2}{c}{ Flexural strength (MPa) } & \multicolumn{2}{c}{ Tension strength (MPa) } \\
\cline { 2 - 8 } & 7days & 28days & 90days & 7days & 28days & 90days & 28days & 90days \\
\hline MC0 & 79.56 & 81.24 & 86.24 & 13.64 & 15.36 & 16.38 & 3.31 & 4.32 \\
MC1 & 81.78 & 87.21 & 90.32 & 13.84 & 15.70 & 17.01 & 3.72 & 4.66 \\
MC2 & 75.13 & 80.21 & 85.53 & 13.03 & 15.04 & 15.93 & 3.29 & 4.27 \\
\hline
\end{tabular}

Table 13: a) Compressive strength measured and predicted using Model-3a of RGRPM.

\begin{tabular}{|c|c|c|c|c|c|c|c|c|c|}
\hline \multirow[t]{2}{*}{ Index } & \multicolumn{3}{|c|}{$\begin{array}{l}\text { Compressive } \\
\text { measured }\end{array}$} & \multicolumn{3}{|c|}{$\begin{array}{l}\text { Compressive strength(MPa) } \\
\text { predicted from Model-3a }\end{array}$} & \multicolumn{3}{|c|}{ Prediction error ${ }^{1}(\%)$} \\
\hline & 7 days & 28days & 90days & 7days & 28days & 90days & 7days & 28days & 90days \\
\hline MC1 & 81.78 & 87.21 & 90.32 & 83.49 & 85.72 & 92.28 & 2.09 & -1.72 & 2.18 \\
\hline MS1 & 82.42 & 88.80 & 92.29 & 84.40 & 86.63 & 93.20 & 2.41 & -2.45 & 0.99 \\
\hline MS2 & 83.23 & 90.21 & 94.47 & 84.86 & 87.08 & 93.66 & 1.95 & -3.47 & -0.86 \\
\hline MS3 & 85.53 & 93.01 & 96.43 & 85.31 & 87.54 & 94.11 & -0.26 & -5.88 & -2.41 \\
\hline MS4 & 82.03 & 87.50 & 91.17 & 85.77 & 87.99 & 94.57 & 4.55 & 0.57 & 3.72 \\
\hline
\end{tabular}
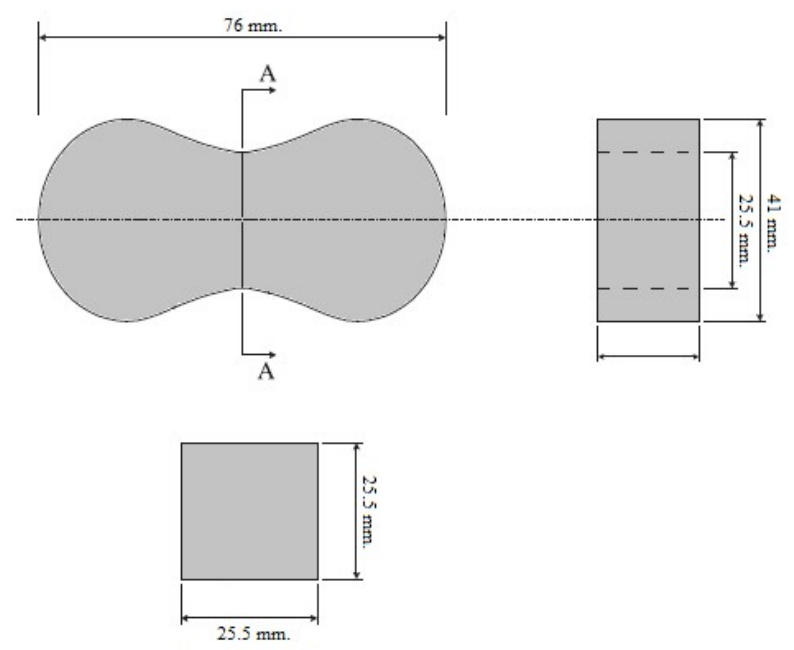

Cross section A-A

Figure 2: Dimensions of the specimens used to test the tensile strength.

\subsection{Flexural strength}

Table $12 \& 14$ indicated the results of the flexural strength of non-reinforced and reinforced reactive mortar. The results were illustrated that MC1 has flexural strength higher than MC0 and MC2 as listed in Table 12. The increase was by 1.5 and $5.9 \%$ respectively at age 7 days and by 2.1 and $4.1 \%$ at age 28 days and by 3.7 and $6.3 \%$ at age 90 days. Besides, the inclusion of the micro steel fibers in MC1 led to improve its' flexural strength as shown in Table 14. The improvement was by $9.7,13.5,17.9$, and $10.5 \%$ at age 7 days and by $6.3,12.4$,
16.3 , and $7.1 \%$ at age 28 days and by 3.2, 10.4, 12.5, and 4.5\% at age 90 days for mortar containing 1, 1.5, 2 and $2.5 \%$ of micro steel fibers respectively as compared to reference mor$\operatorname{tar}$ (MC1). The improvement of the flexural strength comes back to the better compaction and homogeneity of the fiber distribution in MC1. It can also be noticed that the use of more than $2 \%$ of micro steel fiber decreases the improvement in flexural strength, which may be due to the physical difficulties in providing a homogenous distribution of the fibers within the mortar mix [53]. Also, it is observed that the experimental results obtained from the flexural test are somewhat related to the results of the compression test and tension test. Therefore, the values of compressive strength and tensile strength measured in addition to the content of micro-steel fibers and age of specimens were used in multiple linear regression analysis to predict the flexural strength. The regression analyses result gave Model-4a and Model-4b as listed below:

$$
\begin{aligned}
& F S=-12.285+0.466 M S F-0.006 \text { Age }+ \\
& 0.326 \text { CS......Model-4a } \\
& F S \quad=\quad 8.422-0.971 M S F-0.013 \text { Age }+
\end{aligned}
$$

2.106 TS..............Model-4b

Where FS is the flexural strength predicted of green reactive powder concrete ( $\mathrm{MPa}), \mathrm{CS}$ is the compressive strength $(\mathrm{MPa})$ measured at a specified age $(7,28$ or 90 days), TS is tensile strength (MPa) measured at age 28 or 90 days, MSF is the volume fraction (\%) and age is the number of days ( 7,28 or 90$)$. 
Table 13: b) Compressive strength measured and predicted using Model-3b of RGRPM.

\begin{tabular}{lllllll}
\hline Index & \multicolumn{2}{l}{$\begin{array}{l}\text { Compressive } \\
\text { measured }\end{array}$} & strength(MPa) & \multicolumn{2}{l}{$\begin{array}{l}\text { Compressive strength(MPa) } \\
\text { predicted from Model-3b }\end{array}$} & Prediction error ${ }^{2}(\%)$ \\
\cline { 2 - 7 } & 28days & 90days & 28days & 90days & 28days & 90days \\
\hline MC1 & 87.21 & 90.32 & 84.78 & 89.01 & -2.79 & -1.45 \\
MS1 & 88.80 & 92.29 & 87.21 & 90.18 & -1.79 & -2.29 \\
MS2 & 90.21 & 94.47 & 88.45 & 91.46 & -1.95 & -3.19 \\
MS3 & 93.01 & 96.43 & 90.72 & 94.36 & -2.46 & -2.15 \\
MS4 & 87.50 & 91.17 & 88.22 & 91.28 & 0.82 & 0.12 \\
\hline
\end{tabular}

${ }^{2}$ Prediciton error $(\%)=($ Predicted value - measured value $) /($ measured value $) \times 100$

Table 14: a) Flexural strength measured and predicted using Model-4a of RGRPM.

\begin{tabular}{lllllllllll}
\hline Index & \multicolumn{3}{l}{$\begin{array}{l}\text { Flexural strength(MPa) } \\
\text { sured }\end{array}$} & $\begin{array}{l}\text { mea- } \\
\end{array}$ & \multicolumn{7}{l}{$\begin{array}{l}\text { Flexural } \\
\text { dicted from Model-4a }\end{array}$} & strength(MPa) & prediction error ${ }^{2}(\%)$ \\
& 7days & 28days & 90days & 7days & 28days & 90days & 7days & 28days & 90days \\
\hline MC1 & 13.84 & 15.69 & 17.01 & 14.33 & 15.98 & 16.62 & 3.54 & 1.85 & -2.29 \\
MS1 & 15.33 & 16.75 & 17.57 & 15.01 & 16.96 & 17.73 & -2.09 & 1.25 & 0.91 \\
MS2 & 16.00 & 17.92 & 18.98 & 15.51 & 17.65 & 18.67 & -3.06 & -1.51 & -1.63 \\
MS3 & 16.87 & 18.74 & 19.45 & 16.49 & 18.80 & 19.54 & -2.25 & 0.32 & 0.46 \\
MS4 & 15.46 & 16.89 & 17.81 & 15.58 & 17.24 & 18.06 & 0.78 & 2.07 & 1.40 \\
\hline
\end{tabular}

The flexural strength values predicted from Model-4a and Model-4b and the prediction error (\%) were given in Table 14a and 14b. The results indicated that Model- $4 \mathrm{~b}$ is more reliable than Model-4a due to the prediction error (\%) was not excess -3.37 for negative values and 1.21 for positive values.

\subsection{Tensile strength}

The results of the tension test of reinforced and nonreinforced reactive powder mortar were listed in Table 12 \& Table 15. The tension strength of MC1 was higher than MCO and MC2 at age 28 and 90 days. The increase was by 11.0 and $11.6 \%$ respectively at age 28 days and by 7.2 and $8.3 \%$ at age 90 days. The improvement of strength is attributed to the same reasons which led to enhancing compressive strength and the UPV. Moreover, it can be noticed that the reinforcing of $\mathrm{MC} 1$ by $1,1.5,2$, and $2.5 \%$ of micro-steel fibers volume fractions leads to increasing the tension strength as illustrated in Table 15. The increasing of tensile strength was 17.6, 29.3, 38.7, and $30.6 \%$ at age 28 days and by 14.7, 21.7, 31.5 , and $25.5 \%$ at age 90 days for green mortar contained $1,1.5,2$ and $2.5 \%$ of micro steel fibers in comparison with reference green mortar (MC1). From the results obtained in this study, it can be concluded that the inclusion of steel fibers in the cementitious matrix lead to enhancing the tension strength as reported by many researchers $[6,54]$. The tensile strength of reinforced green reactive powder mortar (RGRPM) was predicted using multiple linear regression analysis. The amount of micro steel fibers used in hardened green mortar, the age, and the results of compressive strength measured in the laboratory were considered as independent variables and the tensile strength was considered as a dependent variable. The regression analysis gave Model-5a and Model-5b as shown below:

$T S=3.491+0.798 M S F+0.014$ Age $\ldots . . . .$. Model-5a

$T S=-10.705+0.627 M S F+0.004$ Age + 0.165 CS...........Model-5b

Where MSF is the content of micro steel fibers of green reactive powder concrete (\%), age is the number of days (28 or 90 ) and CS is the compressive strength measured at 28 or 90 days.

The results of tensile strength predicted from Model$5 \mathrm{a}$ and Model-5b and the prediction error (\%) were shown in Table 15. The results indicated that Model-5b is more reliable than Model-5a due to the prediction error (\%) was not excess -2.15 for negative values and 3.87 for positive values. 
Table 14: b) Flexural strength measured and predicted using Model-4b of RGRPM.

\begin{tabular}{lllllll}
\hline Index & \multicolumn{2}{l}{$\begin{array}{l}\text { Flexural } \\
\text { measured }\end{array}$} & strength(MPa) & \multicolumn{2}{l}{$\begin{array}{l}\text { Flexural } \\
\text { dicted from Model-4b }\end{array}$} & strength(MPa) \\
\cline { 2 - 7 } & 28days & 90days & 28days & 90days & Prediction error ${ }^{1}(\%)$ \\
\hline MC1 & 15.70 & 17.01 & 15.89 & 17.06 & 28days & 90days \\
MS1 & 16.75 & 17.57 & 16.59 & 17.78 & 1.21 & 0.29 \\
MS2 & 17.92 & 18.97 & 17.68 & 18.33 & -0.96 & 1.20 \\
MS3 & 18.74 & 19.45 & 18.90 & 19.64 & -1.34 & -3.37 \\
MS4 & 16.89 & 17.81 & 16.93 & 17.99 & 0.85 & 0.98 \\
\hline
\end{tabular}

${ }^{2}$ Prediciton error $(\%)=($ Predicted value - measured value $) /($ measured value $) \times 100$

Table 15: Tensile strength measured and predicted of RGRPM.

\begin{tabular}{|c|c|c|c|c|c|c|c|c|c|c|}
\hline \multirow[t]{2}{*}{ Index } & \multicolumn{2}{|c|}{$\begin{array}{l}\text { Tensile } \\
\text { strength(MPa) } \\
\text { measured }\end{array}$} & \multicolumn{2}{|c|}{$\begin{array}{l}\text { Tensile strength(MPa) } \\
\text { predicted from Model- } \\
5 \mathrm{a}\end{array}$} & \multicolumn{2}{|c|}{$\begin{array}{l}\text { Prediction error }{ }^{2} \\
(\%)\end{array}$} & \multicolumn{2}{|c|}{$\begin{array}{l}\text { Tensile strength(MPa) } \\
\text { predicted from Model- } \\
5 \mathrm{~b}\end{array}$} & \multicolumn{2}{|c|}{$\begin{array}{l}\text { Prediction error }{ }^{2} \\
(\%)\end{array}$} \\
\hline & 28days & 90days & 28days & 90days & 28days & 90days & 28days & 90days & 28days & 90days \\
\hline MC1 & 3.72 & 4.66 & 3.88 & 4.75 & 4.30 & 1.93 & 3.80 & 4.56 & 2.15 & -2.15 \\
\hline MS1 & 4.52 & 5.46 & 4.68 & 5.55 & 3.54 & 1.65 & 4.67 & 5.51 & 3.32 & 0.92 \\
\hline MS2 & 5.26 & 5.95 & 5.08 & 5.95 & -3.42 & 0 & 5.23 & 6.18 & -0.57 & 3.87 \\
\hline MS3 & 6.07 & 6.80 & 5.48 & 6.35 & -9.72 & -6.62 & 6.01 & 6.82 & -0.99 & 0.29 \\
\hline MS4 & 5.36 & 6.25 & 5.88 & 6.75 & 9.7 & 8 & 5.41 & 6.27 & 0.93 & 0.32 \\
\hline
\end{tabular}

${ }^{2}$ Prediciton error $(\%)=($ Predicted value - measured value $) /($ measured value $) \times 100$

\subsection{Failure analysis of green reactive powder mortar}

Figure 3 displays the failure image of reference green mor$\operatorname{tar}$ (MC1) and the best reinforced green mortar (MS3) of the compressive strength, flexural strength, and tensile strength tests. For reference green mortar specimen, brittle failure occurs accompanied by the fall of large parts of it and strong sound during compression test (Figure 3(a1)), a similar failure type occurs accompanied by a division of the specimen into two parts and loud sound during the flexural test (Figure 3(b1)), and tension test (Figure 3(c1)). The green reactive powder mortar contained $2 \%$ of micro steel fibers (MS3) gives similar failure patterns for compressive strength, flexural strength, and tensile strength. Figure 3(a2), 3(b2) \& 3(c2) show that the crack is not forming and expanding quickly. After a crack appears, it slowly propagates and offers excellent ductility after failure.

\section{Conclusions}

Some conclusions are revealed from this study as follows:
1) The use of $8 \%$ of glass powder, $12 \%$ of slag, and $10 \%$ of silica fume as a partial replacement of cement in combination with suitable chemical admixtures allows a reduction of the cement content by as much as $30 \%$, based on the total amount of cementitious material present in the reactive powder mortar. Despite the lower cement content, higher strength values are achieved from the reactive powder mortar.

2) The inclusion of $2.5 \%$ of micro-steel fibers improves the dry bulk density of specimens and gives a higher value as compared with other specimens containing $1,1.5$, and $2 \%$ of micro steel fibers. The increase of density for mortar contained $2.5 \%$ of steel fibers was by $2.2 \%$ at age 28 days and by $2.1 \%$ at age 90 days in comparison with reference mortar. This improvement is due to the high specific gravity of micro steel fibers and the good bond strength between of cementitious matrix and the fibers.

3) The ultrasonic pulse velocity value increases with the increasing content of micro-steel fibers in the mixtures. The high increase was observed at $2 \%$ of volume fraction which was 3.3 and $2.7 \%$ at age of 28 and 90 days in comparison with control mortar.

4) Reactive powder mortar reinforced with $2 \%$ of micro steel fibers gave the best compressive strength compared 


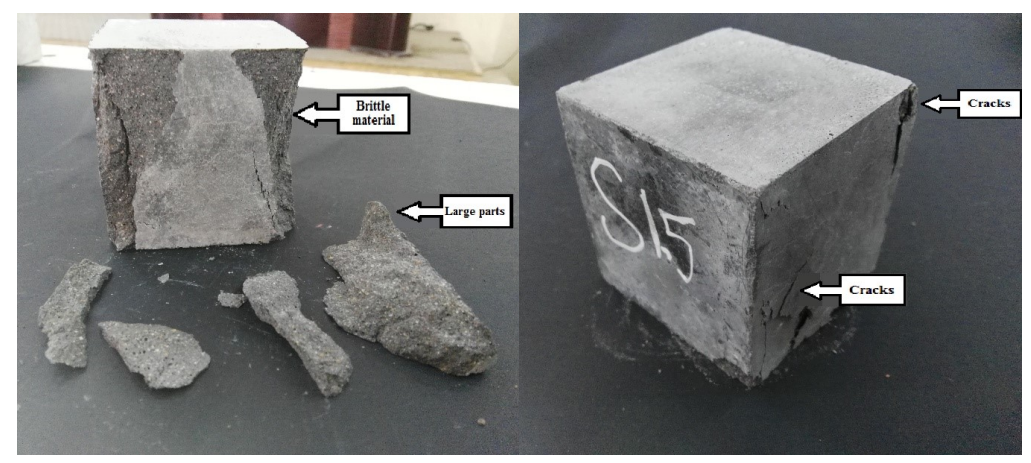

(a) Compressive strength test failure

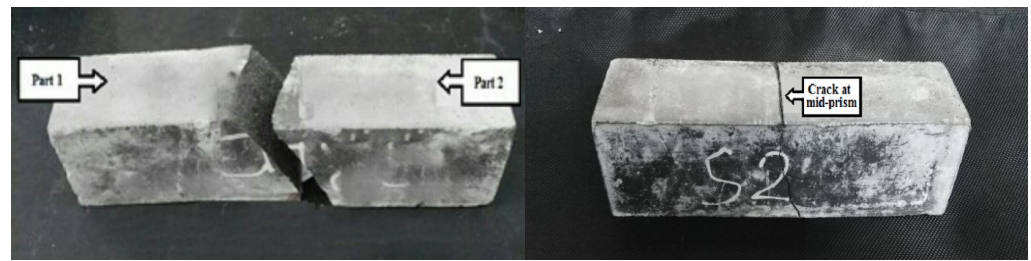

(b) Flexural strength test failure

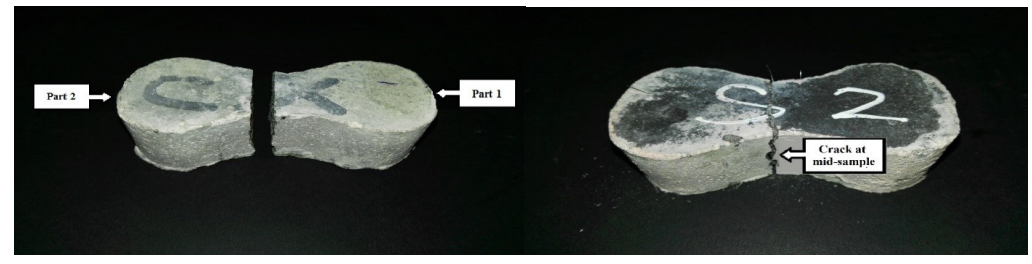

(c) Direct tensile strength test failure

Figure 3: Failure test samples (1 (left) - MC1; 2 (right) - MS3).

with another non-reinforced and reinforced mortar. The reinforcing of mortar with $2 \%$ of micro steel fibers improved the compressive strength by $4.4,6.2$, and $6.3 \%$ at age 7,28 , and 90 days, respectively, compared with reference mortar (MC1).

5) The reinforcing of MC1 with micro-steel fibers was contributed to developing its flexural and tensile strength. The use of $2 \%$ of micro steel fiber volume fractions gave the best result of flexural strength and tensile strength compared with control mortar. The increase was by 17.9, 16.3, and $12.5 \%$ at age 7,28 , and 90 days for flexural strength and by 38.7 and $31.5 \%$ at age 28 and 90 days, respectively, for tensile strength.

6) The obtained models from multiple linear regression analysis give approximate values to the obtained values from experimental work. Model-1b, Model-2, Model-3b, Model-4b, and Model-5b are more reliable to predict UPV, DBD, compressive strength, flexural strength, and tensile strength respectively.
Acknowledgement: The work described in this paper has been conducted in the laboratory of the Technical engineering college of Mosul. This research represents part of the Master's thesis work of the second author.

Funding information: The authors state no funding involved.

Author contributions: All authors have accepted responsibility for the entire content of this manuscript and approved its submission.

Conflict of interest: The authors state no conflict of interest.

\section{References}

[1] Guangjie. Application of reactive powder concrete in highway barriers. Int Conf Transport Eng (ICTE 2009). 2009;86:1232-37.

[2] Dawood ET, Ganim TW. Effectiveness of high performance mortar reinforced with fibers as a repair material. Chall J Concr Res Lett. 
2017;8(2):29-47.

[3] Almayah AA, Latief HS. Mechanical properties of reactive powder concrete (RPC) with various combinations of fibers and ultrafine. Int J Sci Eng Res. 2018;9(12):2229-5518.

[4] Kumar S, Nandhakumar P, Aravind M. Flexural behavior of high strength reactive powder concrete [IJCIET]. Int J Civ Eng Technol. 2017;8(9):648-53.

[5] Okamura H, Ouchi M. Self-compacting concrete. J Adv Concr Technol. 2003;1(1):1-15.

[6] Li H, Liu G. Tensile properties of hybrid fiber-reinforced reactive powder concrete after exposure to elevated temperatures. Int J Concr Struct Mater. 2016;10(1):29-37.

[7] Asteray DB, Oyawa WO, Shitote SM. Compressive and flexural strength of recycled reactive powder concrete containing finely dispersed local wastes. Open J Civil Eng. 2018;8(1):12-26.

[8] Kushartomo W, Bali I, Sulaiman B. Mechanical behavior of reactive powder concrete with glass powder substitute. Procedia Eng. 2015;125:617-22.

[9] Radhi MS, Rasoul ZM, Mahmmod LM. Utilization of pulverized local wastes for production sustainable reactive powder concrete. IOP Conf Series: Mater Sci Eng. 2nd Int Conf Sust Eng Techn. 2019:518022052. https://doi.org/10.1088/1757899X/518/2/022052.

[10] Al-jubory N. Mechanical properties of reactive powder concrete (RPC) with Mineral admixture. Al-Rafidain. Eng J (NY) 2013;80(18):92-101.

[11] Liu J, Wang D. Influence of steel slag-silica fume composite mineral admixture on the properties of concrete. Powder Technol. 2017;320:230-8.

[12] Snellings R, Mertens G, Elsen J. Supplementary Cementitious Materials. Rev Mineral Geochem. 2012;74(1):211-78.

[13] Devi VS, Gnanavel BK. Properties of concrete manufactured using steel slag. Procedia Eng. 2014;97:95-104.

[14] Samad S, Shah A. Role of binary cement including supplementary cementitious material (SCM), in production of environmentally sustainable concrete: A critical review. Int I Sustain Built Envir. 2017;6(2):663-74.

[15] Islam GM, Rahman MH, Kazi N. Waste glass powder as partial replacement of cement for sustainable concrete practice. Int J Sustain Built Environ. 2017;6(1):37-44.

[16] Zhang Z, Zhang B, Yan P. Comparative study of effect of raw and densified silica fume in the paste, mortar and concrete. Constr Build Mater. 2016;105:82-93.

[17] Roslan NH, Ismail M, Majid ZA, Ghoreishiamiri S, Muhammed B. Performance of steel slag and steel sludge in concrete. Constr Build Mater. 2016;104:16-24.

[18] Dawood ET, Abdullah MH. Behavior of non-reinforced and reinforced green mortar with fibers. 2021;67-84.

[19] Kadri E, Duval R. Hydration heat kinetics of concrete with silica fume. Constr Build Mater. 2009;23(11):3388-92.

[20] Tamanna N, Tuladhar R. Sustainable use of recycled glass powder as cement replacement in concrete. Open Waste Manage J. 2020;13(1):1-13.

[21] Norrarat P, Tangchirapat W, Songpiriyakij S, Jaturapitakkul C. Evaluation of strengths from cement hydration and slag reaction of mortars containing high volume of ground river sand and GGBF slag. Adv Civ Eng. 2019;2019:1-12.

[22] Mehta A, Ashish DK. Silica fume and waste glass in cement concrete production: a review. J Build Eng. 2019;29:1-46.
[23] Öner M, Erdoğdu K, Günlü A. Effect of components fineness on strength of blast furnace slag cement. Cement Concr Res. 2003;33(4):463-9.

[24] Sharma SK, Kumar AA, Ransinchung GD, Kumar P. Micro fiber reinforced cement paste and mortar overlays - a review. Int J Pavement Res Technol. 2013;6(6):765-72.

[25] Alrekabi TK, Cunha VM, Barros JA. Reactive powder concrete reinforced with steel fibres exposed to high temperatures. IOP Conf. Series: Mater Sci Eng. 2017: 246012020 https://doi.org/10.1088/1757-899X/246/1/012020.

[26] Yang G, Wei J, Yu Q, Huang H, Li F. Investigation of the match relation between steel fiber and high-strength concrete matrix in reactive powder concrete. Materials (Basel). 2019 May;12(11):1751.

[27] Badagha DG, Modhera CD. Studies On harden properties of mortar using steel fibre [IJERT]. Int J Eng Res Technol (Ahmedabad). 2013;2(6):2278-0181.

[28] Xun X, Ronghua Z, Yinghu L. Influence of curing regime on properties of reactive powder concrete containing waste steel fibers. Constr Build Mater. 2020;232:117129.

[29] Al-Oraimi SK, Seibi AC. Mechanical characterization and impact behavior of concrete reinforced with natural fiber. Compos Struct. 1995;32(1-4):165-71.

[30] Noori A, Shekarchi M, Moradian M, Moosavi M. Behavior of steel fiber-reinforced cementitious mortar and high-performance concrete in triaxial loading. Title No. 112-M11. ACI Mater J. 2015;112(1). https://doi.org/10.14359/51686837.

[31] Shelake SM, Mohite DD, Pise CP, Kadam S, Lakade G, Pawar Y. Mechanical properties of reactive powder concrete under different curing conditions and steel fibers [IJCIET]. Int J Civ Eng Technol. 2018;9(11):2411-9.

[32] Al-Hassani HM, Khalil WI, Danha LS. Mechanical properties of reactive powder concrete with various steel fiber and silica fume contents. Acta Tehnica Corviniensis - Bull Eng; 2014.

[33] Washer G, Fuchs P, Graybeal BA, Hartmann JL. Ultrasonic testing of reactive powder concrete. IEEE Trans Ultrason Ferroelectr Freq Control. 2004 Feb;51(2):193-201.

[34] Shah AA, Ribakov Y, Zhang C. Efficiency and sensitivity of linear and non-Linear ultrasonics to identifying micro and macro-scale defects in concrete. Mater Des. 2013;50:905-16.

[35] Hou X, Abid M, Zheng W, Waqar GQ. Evaluation of residual mechanical properties of steel fiber- reinforced reactive powder concrete after exposure to high temperature using nondestructive testing. Procedia Eng. 2017;210:588-96.

[36] Hassan AM, Jones SW. Non-destructive testing of ultra high performance fibre reinforced concrete (UHPFRC): A feasibility study for using ultrasonic and resonant frequency testing techniques. Constr Build Mater. 2012;35:361-7.

[37] ASTM C778. Standard specification for standard sand. Annual book of ASTM Standards; 2013.

[38] ASTM C1437. Standard test method for flow of hydraulic cement mortar. Annual book of ASTM Standards; 2013.

[39] ASTM C597. Standard test method for pulse velocity through concrete. Annual book of ASTM Standards; 2013.

[40] ASTM C642. Standard test method for density, absorption, and voids in hardened concrete. Annual book of ASTM Standards; 2013.

[41] ASTM C109. Standard test method for compressive strength of hydraulic cement mortars (using 2-in. or [50-mm] cube specimens). Annual book of ASTM Standards; 2013. 
[42] ASTM C348. Standard test method for flexural strength of hydraulic-cement mortars. Annual book of ASTM Standards; 2014.

[43] Nematzadeh M, Poorhosein R. Estimating properties of reactive powder concrete containing hybrid fibers using UPV. Comput Concr. 2017;20(4):491-502.

[44] Oey T, Kumar A, Bullard JW, Neithalath N, Sant G. The filler effect : the influence of filler content and surface area on cementitious reaction rates. J Am Ceram Soc. 2013;96(6):1978-90.

[45] Juenger MC, Siddique R. Recent Advances in understanding the role of supplementary cementitious materials in concrete. Cement Concr Res. 2015;78:71-80.

[46] Ramli M, Dawood ET. High-strength flowable mortar reinforced by steel fiber. Slovak J Civ Eng. 2011;19(3):10-7.

[47] Shao Y, Lefort T, Moras S, Rodriguez D. Studies on concrete containing ground waste glass. Cement Concr Res. 2000;30(1):91100.

[48] Kamali M, Ghahremaninezhad A. An investigation into the hydration and microstructure of cement pastes modified with glass powders. Constr Build Mater. 2016;112:915-24.
[49] Demirboga R. Thermal conductivity and compressive strength of concrete incorporation with mineral admixtures. Build Environ. 2007;42(7):2467-71.

[50] Salman MM, Owaid KM, Hussein DR. Studing the effect of iraqi steel slag addition on the physical and mechanical properties of cement mortar. J Eng Sustain Develop. 2017;21(3):2520-0917.

[51] Rao GA. Investigations on the performance of silica fumeincorporated cement pastes and mortars. Cement Concr Res. 2003;33(11):1765-70.

[52] Khan MI. 14. Nanosilica/Silica Fume. Waste and Supplementary Cementitious Materials in Concrete. Waste and Supplementary Cementitious Materials in Concrete. Elsevier Ltd; 2018.

[53] Markovic I, Walraven J, Mier J. Self compacting hybrid fiber concrete-mix design, workability and mechanical properties. Proc $3^{\text {rd }}$ Int Symp Self-Compact Concr. 2003;763-75.

[54] Chan YW, Chu SH. Effect of silica fume on steel fiber bond characteristics in reactive powder concrete. Cement Concr Res. 2004;34(7):1167-72. 